\title{
The role of physical activity on glucose transporter-4, fasting blood glucose level and glycate hemoglobin in type 2 diabetes mellitus patients in Medan, Indonesia
}

\author{
RINA AMELIA ${ }^{1, A-F}$, JULIANDI HARAHAP ${ }^{1, B, c, ~ E, ~ F, ~ H E N D R I ~ W I J A Y A ~ 2, ~ A, ~ c-E, ~ G ~}$ \\ ORCID ID: 0000-0002-0419-9622 ORCID ID: 0000-0002-1090-2003 ORCID ID: 0000-0002-7309-8227 \\ ${ }^{1}$ Department of Community Medicine/Public Health, Faculty of Medicine, Universitas Sumatera Utara, Medan, \\ Indonesia \\ ${ }^{2}$ Department of Pediatrics, Faculty of Medicine, Universitas Sumatera Utara, Medan, Indonesia
}

A - Study Design, B - Data Collection, C - Statistical Analysis, D - Data Interpretation, E - Manuscript Preparation, F - Literature Search, G - Funds Collection

\begin{abstract}
Summary Background. Physical activity is essential to diabetic patients to improve insulin sensitivity so that diabetes can be well controlled.

Objectives. The purpose of this study was to analyze the effect of physical activity on glucose transporter-4 (GLUT-4), fasting blood glucose level (FBGL) and glycated hemoglobin $\left(\mathrm{HbA}_{1 \mathrm{C}}\right)$ in patients with type 2 diabetes mellitus (T2DM) in Medan.

Material and methods. The study design was analytic with a cross-sectional approach. The study population was T2DM patients, and the number of samples was 83 people who fulfilled the inclusion and exclusion criteria. The study protocol was approved by the research ethics committee at the Faculty of Medicine, Universitas Sumatera Utara, and all participants willing to participate in the study signed written informed consent. The physical activity of T2DM patients was assessed by using a global physical activity questionnaire (GPAQ). The GLUT-4 level was assessed by using the Human GLUT-4 kit, which is ELISA method based. FBGL and HbA ${ }_{1 C}$ levels were determined by using the Doronad affinity + Modified HPLC method. Data was analyzed by the one-way ANOVA statistic test and processed by using SPSS.

Results. The results showed that physical activity affected the level of GLUT-4, FBGL and HbA ${ }_{1 C}$ among T2DM patients.

Conclusions. Medications and diet were not the main determinants of controlled BGL in diabetic patients. However, physical activity is one of the four-element points (education, dietary, physical activity, medicine) in diabetes management that must be implemented to achieve a better quality of life in diabetic patients.

Key words: exercise, glucose transporter type 4, glycated hemoglobin A, blood glucose.
\end{abstract}

Amelia R, Harahap J, Wijaya $\mathrm{H}$. The role of physical activity on glucose transporter-4, fasting blood glucose level and glycate hemoglobin in type 2 diabetes mellitus patients in Medan, Indonesia. Fam Med Prim Care Rev 2021; 23(3): 274-278, doi: https://doi.org/10.5114/ fmpcr.2021.108188.

\section{Background}

The incidence of type 2 diabetes mellitus is increasing worldwide. There is strong evidence that obesity and inactivity are significant factors for this disease [1]. The World Health Organization shows that $60 \%$ of the world's population does not meet physical activity recommendations [2]. Physical activity is defined as any body movement produced by skeletal muscle contractions that increase energy spending above the basal level [3]. Obesity is often considered to be result of either excessive food intake or insufficient physical activity. An obese person has more energy reserves, so even if they consume less amounts of food, they still have energy surplus, so we can say that obesity can be best viewed in energy balance [4].

Lack of activity is one of the contributing factors leading to insulin resistance in T2DM. Individuals with active physical activity have better insulin and glucose profiles than inactive individuals. Therefore, to help control blood sugar, a diabetic patient should perform adequate physical activities, including daily physical activity and regular physical exercise [5]. In addition to maintaining fitness, physical exercise can also help one lose weight and improve insulin sensitivity, thereby improving blood glucose control. Through regular physical exercise, the cells of the body will be trained and more sensitive to insulin so that glucose intake brought by the glucose transporter into the cells increases [6]. The body moves when doing aerobic exercise (such as walking, cycling, gymnastics, jogging), and this can improve the glucose transporter-4 (GLUT-4) translocation process to the surface of muscle cells.

GLUT-4 is the primary glucose transporter and is located primarily in muscle cells and fat cells and plays a role in transporting glucose to skeletal muscle cells [7]. The GLUT-4 protein will be translocated to the surface of skeletal muscle cell membranes after stimulation of a signal from insulin that attaches to insulin receptors in the muscles. Skeletal muscles are the most dominant storage place for glucose conversion besides the liver [8]. Muscle contractions induce translocation of GLUT-4 in the absence of insulin [9]. A study conducted by Cunha et al. found that high intensity exercise induced a significant increase in GLUT-4 levels compared to their controls (not induced by exercise) [10]. In T2DM, physical activity can improve overall glucose control, as demonstrated by a decrease in blood glucose levels and $\mathrm{HbA}_{1 \mathrm{C}}$ concentrations following muscle contractions, which can trigger the insertion of GLUT-4 into the plasma membrane of active muscle cells even when there is no insulin [11].

Aerobic exercise is a type of physical exercise recommended for diabetic patients; aerobic exercise increases oxygen consumption and improves the function of the respiratory and 
cardiovascular system. Proper aerobic exercise improves physiological parameters, including FBGL and the lipid profile. Moreover, it can restore endothelial function and reduce arterial stiffness, which is a determinant of cardiovascular complications in T2DM. Both insulin and exercise increase glucose uptake into the skeletal muscles via GLUT-4 from the intracellular surface to the cell surface. In T2DM, there is a deficiency in the insulin receptor that results in glucose uptake and GLUT-4 translocation, and exercise therapy will repair defects of insulin receptor by providing GLUT-4 translocation [12-14].

\section{Objectives}

The aim of the study was to analyze the effect of physical activity on GLUT-4, FBGL and $\mathrm{HbA}_{1 \mathrm{c}}$ in T2DM patients in Medan.

\section{Material and methods}

\section{Study design}

The study design was analytic with a cross-sectional approach, in which the assessment of physical activity and glycemic control was performed at one time only.

\section{Population and sample}

The study population was T2DM patients in several primary health care centers in Medan (Medan Tuntungan PHC, Medan Belawan PHC, and Medan Amplas PHC), with the sample being 83 patients. The sample size was determined using a sample size formula for one population (with an accuracy of $10 \%$, a significance of 95\%). The inclusion criteria in this study were patients 35-55 years of age (assumed to perform active physical activities), those that had no contraindication to performing physical exercise, those willing to participate the research and those able to perform daily activities independently. The exclusion criteria were severe complication conditions (heart failure, kidney failure, diabetic gangrene) and the presence of comorbidities. Data collection was carried out for two months.

\section{Data measurement}

Assessment of physical activity was carried out using the Global Physical Activity Questionnaire (GPAQ). The GPAQ comprises sixteen questions that collect data from participation in physical activity in three domains: physical activity at work, traveling activity from place to place and recreational or leisure activities [9]. GPAQ measures physical activity through classification with MET (Metabolic Equivalent). MET is the ratio of the metabolic rate during activity to the metabolism rate at rest. MET is depicted in units of $\mathrm{kcal} / \mathrm{kg} / \mathrm{hr}$. The Global Physical Activity Questionnaire has been validated to measure physical activity in the 16-84-year age range $[15,16]$. According to the analysis guide attached to GPAQ, second version, the total physical activity level will be categorized into the following three categories: high performance of a heavy activity, medium-strong activity and low activity. Measurement of GLUT-4, FBGL and $\mathrm{HbA}_{1 \mathrm{C}}$ levels was carried out by examining the blood sample of T2DM patients. GLUT-4 was measured using the Human GLUT-4 ELISA Kit. The kit was based on sandwich enzyme-linked immune-sorbent assay technology. FBGL measurement was performed us- ing a Colorimeter spectrophotometer + fully automatic method, and $\mathrm{HbA}_{1 \mathrm{C}}$ examination was performed using the Doronad affinity + modified HPLC method.

\section{Statistical analysis}

Data was processed by using SPSS 22 for Windows and is displayed in the tables and diagrams. The normality test was performed using the Kolmogorov-Smirnov test $(p>0.05)$. Normally distributed data is presented as mean \pm SD. The one-way ANOVA was used to determine the effect of physical activity on GLUT-4, FBGL and $\mathrm{HbA}_{1 \mathrm{C}}(p<0.05)$.

\section{Ethical approval}

This study was approved by the Research Ethics Committees of Universitas Sumatera Utara, Indonesia (approval number No: 280/KEP/USU/2019).

\section{Results}

\begin{tabular}{|c|c|c|}
\hline Characteristic & $\begin{array}{l}\text { Frequen- } \\
\text { cy }(n)\end{array}$ & $\begin{array}{l}\text { Percent- } \\
\text { age }(\%)\end{array}$ \\
\hline $\begin{array}{l}\text { Gender } \\
\text { male } \\
\text { female }\end{array}$ & $\begin{array}{l}16 \\
67\end{array}$ & $\begin{array}{l}19.3 \\
80.7\end{array}$ \\
\hline $\begin{array}{l}\text { Age group } \\
\text { middle-aged adult ( } 36-45 \text { years of age) } \\
\text { early elderly ( } 46-55 \text { years of age) }\end{array}$ & $\begin{array}{l}12 \\
71\end{array}$ & $\begin{array}{l}14.5 \\
83.5\end{array}$ \\
\hline $\begin{array}{l}\text { Duration of illness } \\
\begin{array}{l}1-5 \text { years } \\
6-10 \text { years } \\
11-15 \text { years } \\
>15 \text { years }\end{array}\end{array}$ & $\begin{array}{l}50 \\
20 \\
11 \\
2\end{array}$ & $\begin{array}{l}60.2 \\
24.1 \\
13.3 \\
2.4\end{array}$ \\
\hline $\begin{array}{l}\text { Diabetes history } \\
\text { father } \\
\text { mother } \\
\text { father and mother } \\
\text { no one }\end{array}$ & $\begin{array}{l}15 \\
15 \\
8 \\
45\end{array}$ & $\begin{array}{l}18.1 \\
18.1 \\
9.6 \\
54.2\end{array}$ \\
\hline $\begin{array}{l}\text { BMI } \\
\text { underweight } \\
\text { normal weight } \\
\text { obese }\end{array}$ & $\begin{array}{l}8 \\
41 \\
34\end{array}$ & $\begin{array}{l}9.6 \\
49.4 \\
41.0\end{array}$ \\
\hline $\begin{array}{l}\text { Blood pressure (systole) } \\
\text { hypertension } \\
\text { no hypertension }\end{array}$ & $\begin{array}{l}66 \\
17\end{array}$ & $\begin{array}{l}79.5 \\
20.5\end{array}$ \\
\hline $\begin{array}{l}\text { Physical activity } \\
\text { high physical activity } \\
\text { medium physical activity } \\
\text { low physical activity }\end{array}$ & $\begin{array}{l}19 \\
13 \\
51\end{array}$ & $\begin{array}{l}22.9 \\
15.7 \\
61.4\end{array}$ \\
\hline
\end{tabular}

Table 1 shows that most of the study subjects were female (80.7\%), early elderly and totaled to 71 participants (83.5\%). Based on the duration of diabetes, most have had diabetes for $1-5$ years (60.2\%). Based on the family history, 45 participants (54.2\%) had a family history of a diabetic mother. Most of the participants had normal nutritional status (49.4\%). Increased blood pressure was experienced by 66 participants (79.5\%). Most diabetic patients had low physical activity, totaling as many as 51 participants (61.4\%).

\begin{tabular}{|l|l|l|l|l|l|}
\hline \multicolumn{6}{|l|}{ Table 2. Glucose transporter-4, fasting blood glucose level, $\mathrm{HbA}_{1 \mathrm{C}}$ level } \\
\hline Parameter & Mean & Median & SD & Min & Max \\
\hline GLUT-4 $(\mathrm{ng} / \mathrm{ml})$ & 2.4 & 2.4 & 0.2 & 2.1 & 2.9 \\
\hline FBGL $(\mathrm{mg} / \mathrm{dl})$ & 248.8 & 240.0 & 108.7 & 87.0 & 600.0 \\
\hline $\mathrm{HbA}_{1 \mathrm{c}}(\mathrm{mg} / \mathrm{dl})$ & 9.4 & 9.1 & 2.8 & 6.0 & 15.8 \\
\hline
\end{tabular}


Table 2 shows the mean GLUT-4, fasting blood glucose and $\mathrm{HbA}_{1 \mathrm{C}}$ levels, which were $2.4 \mathrm{ng} / \mathrm{ml}, 248.8 \mathrm{mg} / \mathrm{dl}$ and $9.4 \mathrm{mg} / \mathrm{dl}$, respectively. In general, this shows poor glycemic control in diabetic patients.

Table 3 shows the results of the ANOVA test. There is a difference in the GLUT-4, FBGL and $\mathrm{HbA}_{1 \mathrm{C}}$ levels based on the physical activity category of diabetic patients in Medan $(p<0.05)$.

\begin{tabular}{|c|c|c|c|}
\hline Parameter & Physical Activity & $F$ & Sig \\
\hline \multirow[t]{3}{*}{ GLUT-4 (ng/ml) } & high physical activity & 3.518 & 0.048 \\
\hline & medium physical activity & & \\
\hline & low physical activity & & \\
\hline \multirow[t]{3}{*}{$\mathrm{BGL}(\mathrm{mg} / \mathrm{dl})$} & high physical activity & \multirow[t]{3}{*}{3.518} & \multirow[t]{3}{*}{0.025} \\
\hline & medium physical activity & & \\
\hline & low physical activity & & \\
\hline \multirow[t]{3}{*}{$\mathrm{HbA}_{1 \mathrm{c}}(\mathrm{mg} / \mathrm{dl})$} & high physical activity & \multirow[t]{3}{*}{3.403} & \multirow[t]{3}{*}{0.038} \\
\hline & medium physical activity & & \\
\hline & low physical activity & & \\
\hline
\end{tabular}

\section{Discussion}

This study showed that the majority of patients had less physical activity. Physical activity is one of the pillars in the management of T2DM and the basis of treatment, as it can affect several aspects, including blood glucose concentration, insulin action and lowering cardiovascular risk factors [17]. Physical activity involves a significant large group of muscles that affect the increase in oxygen uptake and metabolic rate of active muscles. The metabolism process that takes place during physical activity can generate heat, most of which will be wasted through sweat. Sufficient physical activity can control body weight, BGL and, most importantly, can trigger activation of insulin production and make insulin work more efficiently $[18,19]$. Unfortunately, physical activity is still the most frequent aspect ignored by T2DM patients. This study showed that only one third of T2DM patients perform regular physical activity. In fact, physical activity is the most important in maintaining bodily health and in improving the metabolic aspects, as well as other aspects, of T2DM patients [20, 21]. T2DM is a chronic disease that has bad impact to the overall quality of life of the patient due to complications that lead to weakness, tissue damage, and disability [22].

The study results showed a relationship between physical activity and GLUT-4 levels. The more intense the daily physical activity, the higher the levels of GLUT-4. An experimental study was conducted to note the differences in GLUT-4 secretion before and after physical activity. The mean value of plasma membrane content of GLUT-4 is significantly higher after exercise than at rest [18]. Physical exercise for 45-60 minutes whether it is a moderate or an intense physical exercise, physiologically will increase $\mathrm{VO}_{2 \max }$ as much as 60-70\%, and induce GLUT 4 translocation on plasma membrane [23].

In normal muscle cells and fat cells, GLUT-4 is recycled between the plasma membrane and the intracellular storage vesicles. GLUT-4 is distinct from other glucose transporters, and approx. $90 \%$ is located in intracellular conditions when there is no insulin or other stimuli, such as exercise. In the presence of insulin or other stimuli, the balance of this recycling process is altered to support GLUT-4 translocation of intracellular storage vesicles towards the plasma membrane and the transverse tubules in muscle cells. The final effect is to increase the maximum speed of glucose transport into cells [24, 25]. Other studies suggest that the intensity and duration of physical exercise are significant determinants of muscle glucose uptake during physical exercise. Blood glucose can reach up to $40 \%$ of oxidative me- tabolism during physical exercise if physical exercise lasts longer and the glycogen muscles are depleted. Long-term physical exercise results in increased skeletal muscle GLUT-4 immediately after exercise and continues increasing for several hours after exercise, but it can return to normal levels within 24 hours [26, 27]. Physical activity will increase GLUT-4 so that insulin secretion increases, resulting in better glucose metabolism.

This study results showed the differences in FBGL and $\mathrm{HbA}_{1 \mathrm{C}}$ levels based on the physical activity performed by T2DM patients. Regular exercise could decrease $\mathrm{HbA}_{1 \mathrm{c}}$ increase muscle strength and decrease inflammatory markers in the elderly with diabetes [28]. Aerobic exercise is more effective in lowering $\mathrm{HbA}_{1 \mathrm{c}}$ levels than weight training. More than 150 minutes of weekly physical exercise is more effective in lowering $\mathrm{HbA}_{1 \mathrm{c}}$ levels than physical exercise less than 150 minutes per week $[29,30]$. The effect of insulin on the muscles and the liver can be modified either by acute physical exercise or regular physical exercise. Acute aerobic exercise increases muscle glucose uptake up to five-fold through an insulin-independent mechanism. Meanwhile after a prolonged exercise the muscle glucose uptake will be increased through 2 hours insulin dependent mechanism and up to 48 hours insulin-independent mechanism [31].

In T2DM, the increased glucose uptake into cells during aerobic physical exercise will decrease blood glucose levels so that $\mathrm{HbA}_{1 \mathrm{c}}$ levels also decrease. As BGL decreases and cells are not in a state of glucose deficiency, the process of catabolism of energy stores, such as fats and proteins, will also decrease so that the blood glucose levels will decrease as well. Some studies have also mentioned the correlation of physical activity with decreased triglyceride levels and total cholesterol in diabetic patients who regularly perform adequate physical activity [32, 33]. Decreased mean blood sugar, $\mathrm{HbA}_{1 \mathrm{C}}$ Total Cholesterol (TC), LDL-C, HDL-C and triglyceride levels were found after moderate physical activity with $a \geq 150 \mathrm{~min} /$ week duration. In moderate and intensive physical activity, mean $\mathrm{BGL}, \mathrm{HbA}_{1 \mathrm{C}^{\prime}} \mathrm{TC}$, LDL-C, $\mathrm{HDL}-\mathrm{C}$ and triglyceride levels were found to decrease after physical activity for $\geq 150$ minutes/week. In addition, mean BGL, $\mathrm{HbA}_{1 \mathrm{c}^{\prime}}$ cholesterol, LDL, HDL and triglyceride levels were found to decrease after intensive physical activity for $\geq 75$ minutes/ /week and $\geq 150$ minutes/week [34, 35]. Another supporting study stated that patients undergoing aerobic physical exercise for eight weeks obtained improved blood glucose control with significantly decreased $\mathrm{FBGL}$ and $\mathrm{HbA}_{1 \mathrm{C}}$ levels $[36,37]$.

\section{Conclusions}

The results of this study indicate that there is an effect of physical activity on the levels of GLUT-4, BGL and $\mathrm{HbA}_{1 \mathrm{C}}$ in T2DM. Most of the T2DM patients only partook in low physical activity, which lead to uncontrolled diabetes as shown by higher mean GLUT-4, fasting blood glucose and $\mathrm{HbA}_{1 \mathrm{C}}$ levels. In diabetic patients, medications and diet are not the only main means to control BGL. However, physical activity is one of the four-element points (education, dietary, physical activity, medicine) in diabetes management that must be implemented to achieve a better quality of life in diabetic patients.

\section{Limitations of the study}

This study is a cross-sectional study. The assessment of physical activity in this study is for general physical activity. The following research plan will provide regular physical exercise interventions to assess the effectiveness of regular physical exercise in increasing GLUT-4 secretion and blood sugar control in T2DM patients in Medan City.

Acknowledgments. The authors gratefully thank to The Ministry of Research, Technology, and Higher Education, for funding this study through the agreement of Research and Community Service Fund, for the Fiscal year 2018. 
Source of funding: This paper was developed under the research project and supported by the Directorate of Research and Community Service of the Directorate-General for Research and Development of the Ministry of Research, Technology and Higher Education by the agreement of Funding Research and Community Service for the Fiscal Year 2018.

Conflicts of interest: The authors declare no conflicts of interest.

\section{References}

1. Turkson RKD. The impact of a nutrition and physical activity intervention programme on frailty syndrome in elderly citizens in Lesotho [doctoral dissertation]. University of the Free State; 2018.

2. World Health Organization. Global action plan on physical activity 2018-2030: more active people for a healthier world. WHO; 2018. Available from URL: https://apps.who.int/iris/bitstream/handle/10665/272722/9789241514187-eng.pdf.

3. Hamilton MT. The role of skeletal muscle contractile duration throughout the whole day: reducing sedentary time and promoting universal physical activity in all people. J Physiol 2018; 596(8): 1331-1340.

4. Kaupužs A. The relationship between physical activity and exercise motivation of the first-year students from Rezekne Augstskola. J Sports Sci 2013; 4(1): 3-15.

5. Hill JO, Wyatt HR, Peters JC. Energy balance and obesity. Circulation 2012; 126(1): 126-132.

6. Paramitha GM. Hubungan Aktivitas Fisik Dengan Kadar Gula Darah Pada Pasien Diabetes Melitus Tipe 2 di Rumah Sakit Umum Daerah Karanganyar [doctoral dissertation]. Universitas Muhammadiyah Surakarta; 2014.

7. Petersen MC, Shulman GI. Mechanisms of insulin action and insulin resistance. Physiol Rev 2018; 98(4): 2133-2223.

8. Lauritzen HP, Schertzer JD. Measuring GLUT4 translocation in mature muscle fibers. Am J Physiol Endocrinol Metab 2010; 299(2): E169-E179.

9. Messina G, Palmieri F, Monda V, et al. Exercise causes muscle GLUT4 translocation in an insulin. Biol Med (Aligarh) $2015 ; 3: 7$.

10. Cunha VN, Paula Lima M de, Motta-Santos D, et al. Role of exercise intensity on GLUT4 content, aerobic fitness and fasting plasma glucose in type 2 diabetic mice. Cell Biochem Funct 2015; 33(7): 435-442.

11. Lisiswanti R, Cordita RN. Aktivitas fisik dalam menurunkan kadar glukosa darah pada diabetes melitus tipe 2. Jurnal Majority 2016; 5(3): 140-144 (in Indonesian).

12. Aggarwala J, Sharma S, Saroochi AJ, et al. Effects of aerobic exercise on blood glucose levels and lipid profile in diabetes mellitus type 2 subjects. Al Ameen J Med Sci 2016; 9(1): 65-69.

13. Putri EL. Hubungan antara latihan jasmani dengan kadar glukosa darah penderita diabetes. Jurnal Berkala Epidemiologi 2016; 4(2): 188-199 (in Indonesian).

14. Flores-Opazo M, Boland E, Garnham A, et al. Exercise and GLUT4 in human subcutaneous adipose tissue. Physiol Rep 2018; 6(22): e13918.

15. Obradovic M, Nesic G, Popovic A, et al. Physical activity and eating habits of students of the University of Belgrade: an epidemiological study. Vojnosanitetski Pregled 2020, doi: 10.2298/VSP2005100560.

16. Mohan R, Manipal S, Raj N, et al. Evaluation of physical activity and body mass index among dental professionals in Chennai City, Tamilnadu, India. IJSRDMS 2017; 2(5): 7.

17. Haible S, Volk C, Demetriou Y, et al. Promotion of physical activity-related health competence in physical education: study protocol for the GEKOS cluster randomized controlled trial. BMC Public Health 2019; 19(1): 1-5.

18. Indonesia PE. Pengelolaan dan pencegahan diabetes melitus tipe 2 di Indonesia. Jakarta: PB Perkeni; 2015 (in Indonesian).

19. Luo B, Zhang J, Hu Z, et al. Diabetes-related behaviours among elderly people with pre-diabetes in rural communities of Hunan, China: a cross-sectional study. BMJ Open 2018; 8(1): e015747, doi: 10.1136/bmjopen-2016-015747.

20. Navale AM, Paranjape AN. Glucose transporters: physiological and pathological roles. Biophys Rev 2016; 8(1): 5-9.

21. Amelia R, Yunanda Y. Relationship between depression and glycemic control among patients with type 2 diabetes in Medan. InI OP Conference Series: Earth and Environmental Science 2018; 125(1): 012170, doi: 10.1088/1755-1315/125/1/012170.

22. Dwi Puspihapsari L, Widodo A, Kep A. Pengaruh Senam Diabetes Mellitus terhadap Penurunan Kadar Gula Darah Sewaktu (GDS) Peserta Prolanis di Puskesmas Purwodiningratan [doctoral dissertation]. Universitas Muhammadiyah Surakarta; 2019.

23. Amelia R. The correlation between Body Mass Index and self-efficacy with blood glucose level in Type 2 Diabetes Mellitus. Adv Sci Lett 2017; 23(4): 3606-3609.

24. Flores-Opazo M, McGee SL, Hargreaves M. Exercise and GLUT4. Exerc Sport Sci Rev 2020; 48(3): 110-118.

25. Duarte CK, Almeida JC de, Merker AJ, et al. Physical activity level and exercise in patients with diabetes mellitus. Rev Assoc Med Bras 2012; 58(2): 215-221.

26. Riddell MC, Pooni R, Yavelberg L, et al. Reproducibility in the cardiometabolic responses to high-intensity interval exercise in adults with type 1 diabetes. Diabetes Res Clin Pract 2019; 148: 137-143.

27. Richter EA, Hargreaves M. Exercise, GLUT4, and skeletal muscle glucose uptake. Physiol Rev 2013; 93(3): 993-1017.

28. Esteves JV, Enguita FJ, Machado UF. MicroRNAs-mediated regulation of skeletal muscle GLUT4 expression and translocation in insulin resistance. J. Diabetes Res 2017; 2017: 7267910, doi: 10.1155/2017/7267910.

29. Osei-Yeboah J, Owiredu W, Norgbe G, et al. Physical activity pattern and its association with glycaemic and blood pressure control among people living with diabetes (PLWD) in the Ho municipality, Ghana. Ethiop J Health Sci 2019; 29(1): 819-830.

30. McGinley SK, Armstrong MJ, Boulé NG, et al. Effects of exercise training using resistance bands on glycaemic control and strength in type 2 diabetes mellitus: a meta-analysis of randomised controlled trials. Acta Diabetol 2015; 52(2): 221-230.

31. Boniol M, Dragomir M, Autier $\mathrm{P}$, et al. Physical activity and change in fasting glucose and HbA1c: a quantitative meta-analysis of randomized trials. Acta Diabetol 2017; 54(11): 983-991.

32. Colberg SR, Sigal RJ, Yardley JE, et al. Physical activity/exercise and diabetes: a position statement of the American Diabetes Association. Diabetes Care 2016; 39(11): 2065-2079.

33. Huang JH, Cheng FC, Tsai LC, et al. Appropriate physical activity and dietary intake achieve optimal metabolic control in older type 2 diabetes patients. J Diabetes Investig 2014; 5(4): 418-427.

34. Meenu J, Jadeja Jayendrasinh $\mathrm{M}$, Neeta M. Correlation between $\mathrm{HbA}_{1 \mathrm{c}}$ values and lipid profile in type 2 diabetes mellitus. IJBAP 2013; 2(1): 47-50, doi: 10.5281/zenodo.4479182.

35. Carral F, Gutiérrez JV, Carmen Ayala M del, et al. Intense physical activity is associated with better metabolic control in patients with type 1 diabetes. Diabetes Res Clin Pract 2013; 101(1): 45-49. 
36. Amelia R, Harahap J, Lelo A, et al. Risk analysis for cardiovascular complication based on the atherogenic index of plasma of type 2 diabetes mellitus patients in Medan, Indonesia. Fam Med Prim Care Rev 2020; 22(3): 197-201.

37. Banitalebi $\mathrm{E}$, Kazemi A, Faramarzi $\mathrm{M}$, et al. Effects of sprint interval or combined aerobic and resistance training on myokines in overweight women with type 2 diabetes: a randomized controlled trial. Life Sci 2019; 217: 101-109.

Tables: 3

Figures: 0

References: 37

Received: 28.02.2021

Reviewed: 17.04 .2021

Accepted: 08.06.2021

Address for correspondence:

Rina Amelia, MD, PhD

Department of Community Medicine and Public Health

Faculty of Medicine

Universitas Sumatera Utara

Jl. dr. Mansyur No. 5 Kampus USU Medan

20155 Medan

Indonesia

Tel.: +62 8126444284

E-mail:rina2@usu.ac.id 